\title{
PARTICIPATORY IN KAMPUNG'S CO-HOUSING DEVELOPMENT: LEARNING FROM KAMPUNG MUKA, NORTH JAKARTA
}

\author{
Dinda Lutfiyah ${ }^{1}$, Herlily $^{1 *}$ \\ ${ }^{1}$ Department of Architecture, Faculty of Engineering, Universitas Indonesia, Depok 16424, \\ Indonesia
}

(Received: August 2018 / Revised: August 2018 / Accepted: January 2019)

\begin{abstract}
Since its first appearance in Denmark in 1960s, co-housing communities responded basic needs for residents with a combination of the fulfillment of individual privacy and the benefit of community life. Kampung Muka as one of community indirectly has implemented some of the co-housing principles according to the local context. Participation in community life becomes in the form of participatory value which is one of the co-housing principles. Forth, this form of participatory is being learned on how its application and the impact of negotiating spaces in Kampung Muka. This writing aimed to redefine the co-housing concept according to the local context in Jakarta and expected to be able to suggest a new understanding of the society about co-housing concept according to the local context.
\end{abstract}

Keywords: Co-housing; Local Context; Negotiating Spaces; Participatory

\section{INTRODUCTION}

Co-housing or community housing is a housing concept performed by collaborative and participatory actions which later known as a form of intentional communities (Jarvis, 2010). The concept aims to increase social interaction in the community. One of an architect in the United States, Grace Kim, in a TedTalks conference talked about how she noticed 'loneliness' as one of the effects of the common housing type nowadays. Having a big house, big fences or even big courtyards has become the people's paradigm in this era (Kim, 2017).

The social actions in that type of neighborhood, residents do not know each other, everybody is busy with their household affairs. This leads to the idea of antidote isolation concept, carried by the architect (Kim, 2017) as a remedy to the 'loneliness' phenomenon that adapted the collaborative housing concept developed in Denmark's society in the 1960s.

"Co-housing is an intentional neighborhood where people know each other and look after one another" (Grace Kim, $7^{\text {th }}$ August 2017).

Furthermore, co-housing evolved in many countries such as United States, United Kingdom, and Japan. The developed co-housing communities are applying participatory principals by stacking their houses and dividing private space and communal space. In that communal space, social interaction arose and became the support factor in an antidote isolation movement (Kim, 2017). This might create participatory value for the people in the community life in the future.

*Corresponding author's email: herlily@gmail.com 
The type of planned housing settlements in Jakarta -Rumah Susun, and flats - are pushing people to live individually and not supporting social interaction around the neighborhoods. Whereas, the concept of co-housing was already applied in the local context residents in urban kampungs in Indonesia, unconsciously. This matter can be seen in shared living or extended family housing which showed that 'collaboration' element as proposed in the co-housing concept has been applied in the local context.

\section{METHODS}

This paper is normative research, also known as legal literature research which is conducted by analyzing literature or secondary data that covers research on legal principles, the legal system, legal comparison, and legal history. Normative legal research is designated to assess the qualitative value of a legal norm. In this case, this paper will assess the current public participation in environmental management in Indonesia and the possible methods to resolve the problem. This paper uses a qualitative approach which aims to create an understanding regarding problems in the current public participation mechanism in environmental management in Indonesia.

In this learning, the pattern of the domestic negotiating spaces in one of the kampungs in Jakarta Utara was conducted. Two methods can be performed, the first method is spatial ethnographic, such as interview and field observation, and the second method is surveyed, about doing some mapping of the pattern in the kampung. This paper aims to redefine the concept of co-housing according to the local context. The participatory process observed would affect negotiating spaces that was expected to suggest a new understanding for the society about co-housing according to the local context.

\subsection{Theoretical Review}

Ruiu (2015) explains that co-housing practices create communities with the same vision and mission to live in the area. After that, the people in the community would evolve their social interaction to support sustainable community development. Developing co-housing requires the provision of a cohesive group, common goals, and a physical site. Community development in co-housing tends to need a longer time to create a strong group that may come over problems that arise during co-housing community development process phases.

According to Tuckman (1965) in Ruiu (2015) and Jarvis (2010), there are four stages of group development. The first stage is called 'forming,' that is when people are starting to know each other. It is characterized by each member of the group runs independently, and at the same time, they share common values. The next stage is called 'storming', a stage when conflicts arise within the community. This stage represents a fundamental stage of 'maturation' from which some groups might ever emerge. Conflicts emerge, and some of the members of the group choose to move out of the group.

As time goes by, the group start to adopt rules to become more cohesive. This third stage called 'norming', a stage where agreement and big consensus can be achieved effectively. Last, called 'performing', when the rules perform well and more flexible because of trust enhancement between the member of the group so that the group functions can be reached without conflict as a unit.

In co-housing communities, people will develop a strong sense of belonging because of active participation in decision-making and designing process (Dioguardi, 2010 in Ruiu, 2015). Forth, the experts say that participation in the decision-making process is a key element in social interaction (Mc. Camant \& Durret, 1998; Brenton, 1998 in Ruiu, 2015). 
Six components may apply in many forms from urban, suburban, to rural (Durrett, 2009). First, 'participatory process', indicated by the residents who participate in designing house development and at the same time be responsible as a group to meet agreements on a decisionmaking process. The second is 'deliberate neighborhood design', one of the most important things in co-housing development. This can be achieved by designing a physical environment that encourages a strong sense of belonging atmosphere.

Third, 'common facilities', as a supplement to the private houses. This common area is the heart of a co-housing community, providing a space for common activities in the co-housing community. The using of common facilities is then managed in the fourth component called 'complete resident management'. Residents are responsible for the community's ongoing management. Meetings are held to discuss and solve the problems that occur in the community.

Co-housing is also characterized by the absence of a single person, the term called "nonhierarchical social structure'. Furthermore, each member of the group doesn't dominate the decision-making and community development process. Cohousing's residents are also responsible for their incomes (Christensen \& Levinson, 2003) so in co-housing, there is a component called 'separate income sources'. It can be achieved with no rules of shared residents' income source within the member of the group. Each member has their income sources.

According to McCamant \& Durrett (1998) in (Ruiu, 2017), the formula of co-housing development comes from resident's willingness to make the certain situation that creates mutual benefits, from their daily life to their community life. It could be triggered by adopting a participatory mechanism as a key to lead their community development process (Ruiu, 2017). The participatory process starts with the resident's involvement in designing architecture layout in the community (Ruiu, 2017).

By assuming the participation of each member in co-housing starts from the early stage of the development process, they are required to act as a single entity to identify a solution for the whole community's advantage (Ruiu, 2017). Thus, even if the community has been formed, the agreement of each member of the group related to mutual benefit should be discussed by all members of the group in the first place. Any individual choices, which may affect the whole community, should be shared and negotiated by all members (Ruiu, 2017). Therefore, residents should understand that the community development process is relying on the negotiation between individual interest and common interest (Ruiu, 2017).

Co-housing involves the residents in their decision-making to develop a social relationship and social capital (Williams, 2005). Even though 'participation' system is used more often in involvement and consensus process, voting is also used if the problems are more difficult to achieve by agreement (Ruiu, 2017). What affects the community's sustainability in co-housing is a social relationship, mutual relationship, and caring about the community life.

From the theoretical review, there are several points to be considered in learning the local context of kampung and connecting to existing co-housing theory. Most of the formation of cohousing community formed intentionally which may have different application in the local context. The co-housing community is formed through four stages of group development; there are six co-housing components that can apply in the local context; participatory process is the fundamental value in developing co-housing community. 


\section{RESULTS AND DISCUSSION}

\subsection{Learning Co-housing in Kampung Muka}

Kampung Muka is located behind the Jakarta Kota Station and BNI Bank 46 building, alongside with Mangga Dua Market and Kota Tua area. If we look to the historical background, this kampung was formerly known as Kampung Kebun Sayur because the livelihood majority of the population is farmers. Kampung Muka was also known as a workshop place for the transmigration government program that made Kampung Muka had many warehouses around the kampung. Today, Kampung Muka consists of seven $\mathrm{RT}^{1} \mathrm{~s}$ with a registered population of around 800 households, most of them are people that came from outside Jakarta (Bahrunsyah, Head of RW 04, interviewed 2018). In doing this observation studies on the field, the mapping method is used to point out several places, especially those involving community participation in using the spaces. The observation took place in Kampung Muka RW²04, North Jakarta.
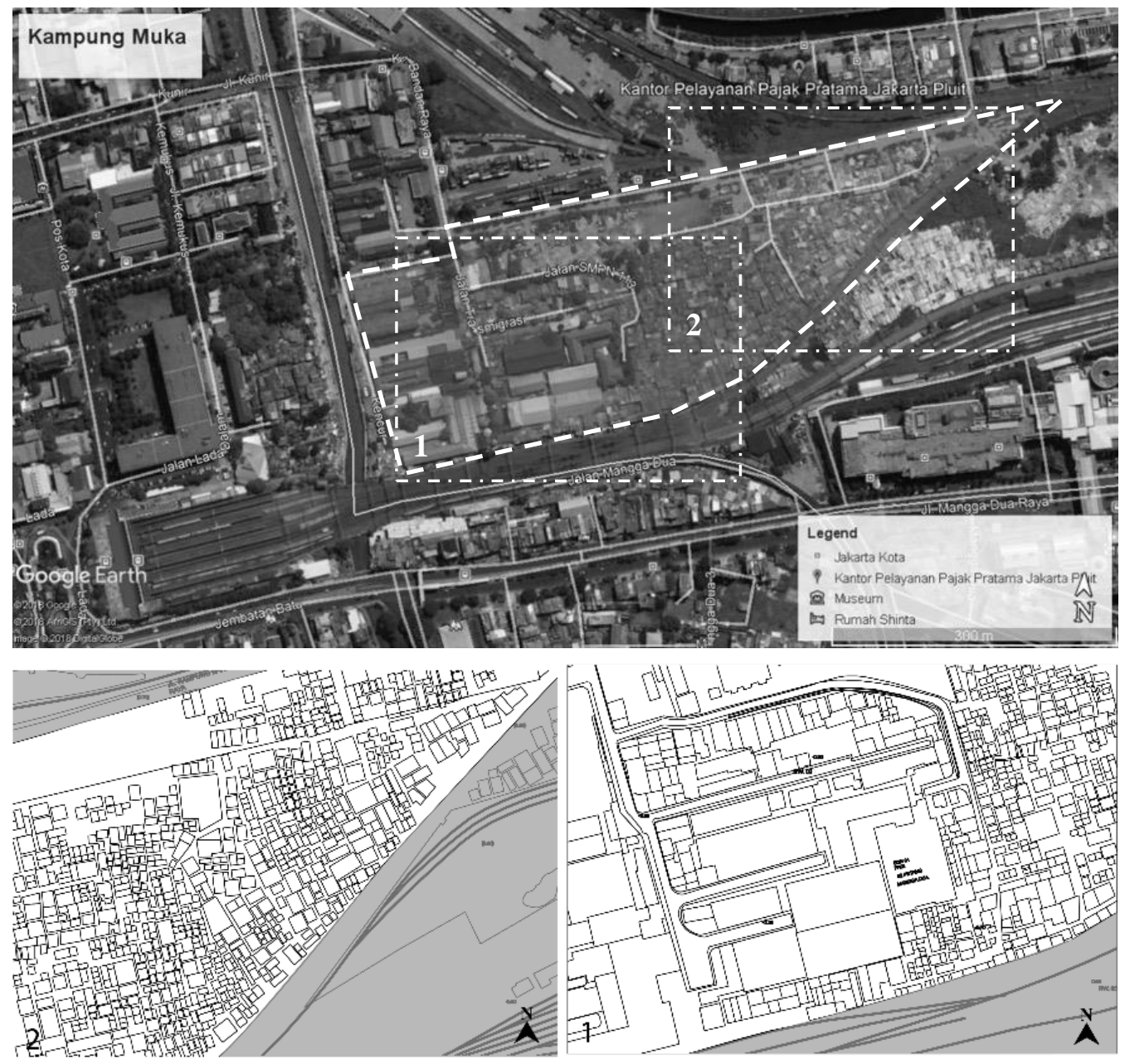

Figure 1 Location of RW04 Kampung Muka and the analysis area.

Source: Google Earth, personal visualization

Warung ${ }^{3}$ became one of the common space for people in Kampung Muka to interact intentionally or unintentionally. The spot of warung spread almost every two to three houses along the road in each alley. It becomes the opportunity to open a store as one of the main

\footnotetext{
${ }^{1}$ Rukun Tetangga, consists of 10 to 20 households. It refers to neighbourhood association

${ }^{2}$ Rukun Warga, consists of 5 to 10 RT. It refers to community association

${ }^{3}$ Refers to a place to sell food, hygiene products, snacks, etc, according to local context in Indonesia.
} 
livelihood for wives. Most of the husbands in Kampung Muka work as traders in Kota Tua and Mangga Dua area.

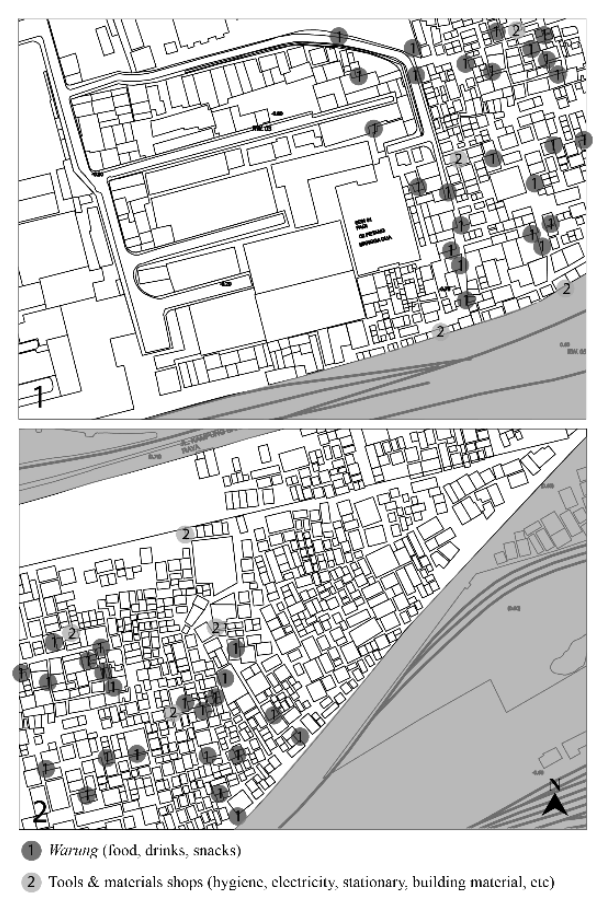

a

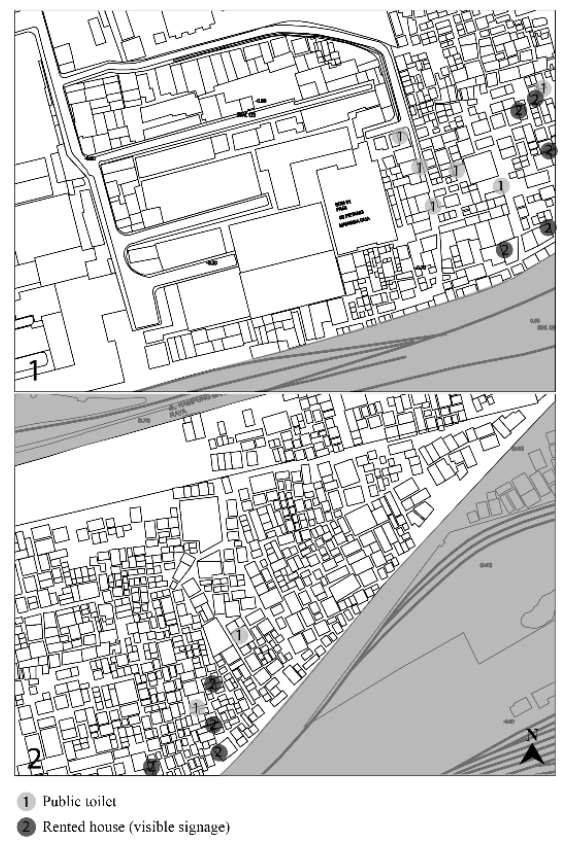

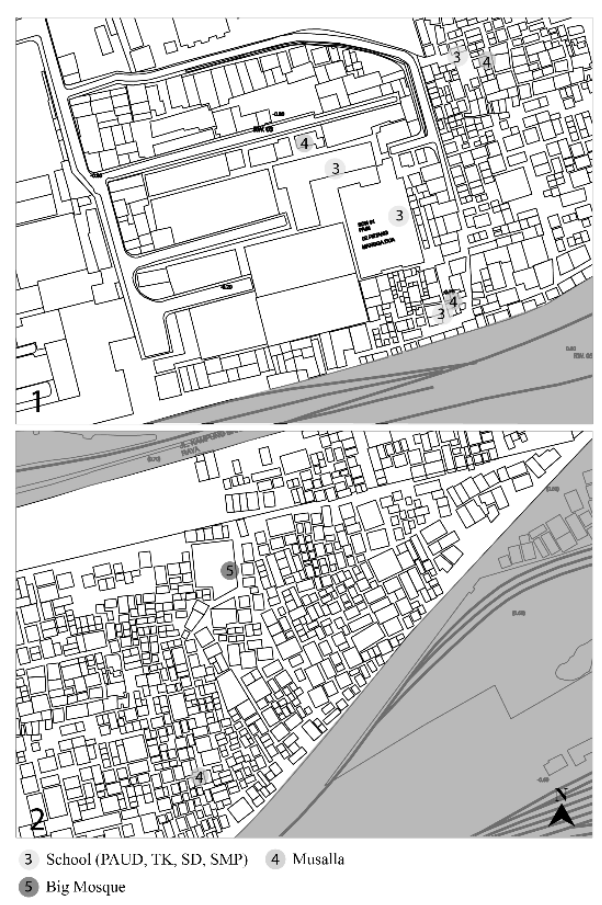

b
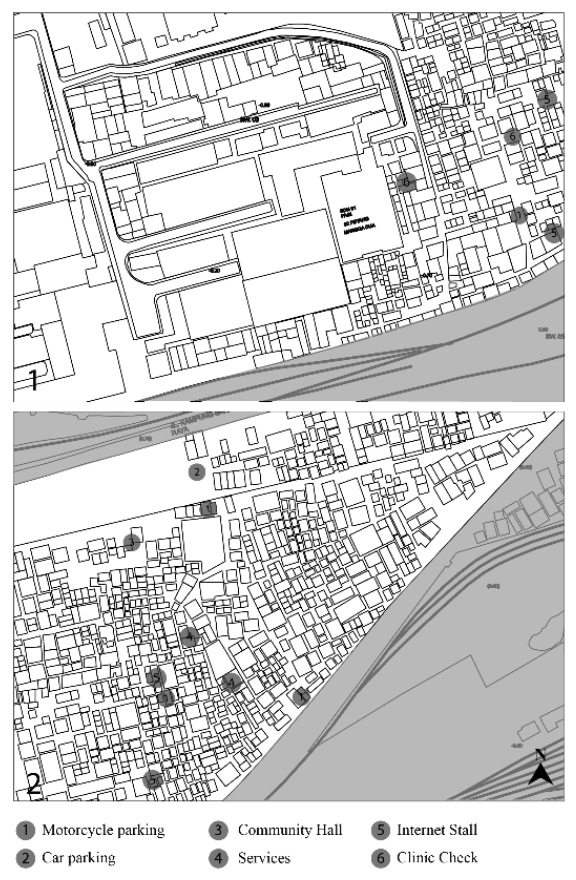

d

Figure 2 Map point: (a) Warung; (b) Musallas \& schools; (c) Public toilet \& rented houses; (d) another public and social facilities

Source: Field report, 2018

The space in front of the warung often used as a deliberate social interaction space. As with mosques, people work together to build mosques and make them a gathering area for deliberation. Their mosque is known as a large mosque which is one of the real forms of 
community participation, in the form of collective funding and building. Some of them located nearly to educational facilities such as early childhood, kindergarten, elementary school $\left(\mathrm{SD}^{4}\right)$, and junior high school $\left(\mathrm{SMP}^{5}\right)$.

For the other common facilities, public toilets are considered as a shared facility that provides a solution for most communities in Kampung Muka that lack room to do their household activities. People in Kampung Muka use the front or side of his alley as a room to wash their dishes, clothes, and bath their child. They also use the alley to be their 'spontaneous' kitchen for the cooking area, to respond to their space limitations phenomenon.

Other public and social facilities in Kampung Muka, each provides space for its residents to perform activities that cannot be done at home. The area for motor vehicle parking is made near the highway and access to the outskirts of the kampung that runs along the edge of the railroad tracks. Its located close to the large mosque allows many residents to gather in these areas.

The mapped point indicates how the public and social facilities influence the existence of the community gathering space around them. The unconscious negotiating spaces foster a high sense of tolerance among the Kampung Mukai people in using every space. Space use is done in various ways. They are starting from the mothers who do the cooking activities in the front area of his house, chatting with other residents and enjoying the spare time, the children who make the alley in front of his house for the play area, to the fathers who supervise his children to prevent disturbing their mothers. Each of the actors in the alley has their respective roles to achieve their goals in living their daily lives in Kampung Muka.

Based on the results of interview and field observations explored through the history of Kampung Muka, the initial analysis found is the formation of space on the Kampung Muka constituted by the abundance of unused empty areas which then built the building. Immigrants have no specific rules for living in Kampung Muka. The formation of a dynamic move by looking at the phenomenon of the migrants responds to the context of the Kampung Muka region by moving spontaneously in building its new livelihood. The dynamism that occurs in the kampung also allows each citizen to experience the stages of community formation with different steps.

Some of the tables below explain how the dynamics of the movement of the kampungs in Kampung Muka in shaping and adapting in the co-housing community by the local context. It can be assumed that in the process of forming Kampung Muka, the stages that apply in it move dynamically because there are no fixed rules that settled in life in the kampung. Each citizen can feel their stages of community formation that shows how they adapt in facing life in Kampung Muka neighborhood.

Table 1 History of Co-housing Development in Kampung Muka: study case of $\mathrm{Ibu}^{6}$ Imeh and Ibu Rere's family

\begin{tabular}{l|l}
\hline Stages of Group Development & Ibu Imeh and Family in Developing Kampung Muka \\
\hline $\begin{array}{l}\text { Performing } \\
\text { Formed because of the belief that } \\
\text { vacant land is a potential to be built }\end{array}$ & $\begin{array}{l}\text { At that time, there were only four houses in the } \\
\text { kampung. Ibu Imeh's grandmother started her new life }\end{array}$ \\
$\begin{array}{l}\text { houses without caring in advance } \\
\text { in Kampung Muka in 1975 after relocated from } \\
\text { in problems that will occur. }\end{array}$ & Tanjung Priok, until Ibu Imeh was born in 1978. \\
\hline \begin{tabular}{l} 
Storming \& Forming \\
\hline
\end{tabular}
\end{tabular}

\footnotetext{
${ }^{4}$ Sekolah Dasar

${ }^{5}$ Sekolah Menengah Pertama

''Ibu' or 'Bu' refer to women whose older and to show politeness.
} 


\begin{tabular}{|c|c|}
\hline Stages of Group Development & Ibu Imeh and Family in Developing Kampung Muka \\
\hline $\begin{array}{l}\text { Developed when the number of } \\
\text { immigrants from outside Jakarta } \\
\text { increased and raised different } \\
\text { opinions amongst them, and at the } \\
\text { same time, people started to know } \\
\text { each other. }\end{array}$ & $\begin{array}{l}\text { Ibu Imeh and family's life journey begins with many } \\
\text { obstacles, such as facing PJKA }{ }^{7} \text { officers, disagreement } \\
\text { between immigrant residents and elders residents, and } \\
\text { stating the vacant land. }\end{array}$ \\
\hline $\begin{array}{l}\text { Norming } \\
\text { The existence of community } \\
\text { organizations began to facilitate the } \\
\text { survival of Kampung Muka by } \\
\text { forming several rules that are then } \\
\text { agreed to the common interest. }\end{array}$ & $\begin{array}{l}\text { Ibu Imeh also participated to become part of the } \\
\text { community organization by going to PKH } \\
\text { management group until becoming Chairman of PKH } \\
\text { until now. Ibu Imeh and family also actively } \\
\text { participate in deliberations held by other community } \\
\text { organizations such as RT and RW to maintain the } \\
\text { continuity of life in Kampung Muka. }\end{array}$ \\
\hline \multirow[t]{2}{*}{$\begin{array}{l}\text { Performing } \\
\text { After having a community } \\
\text { organization in Kampung Muka, } \\
\text { residents began to trust the function } \\
\text { and role of the organization. The } \\
\text { conflict began to be resolved } \\
\text { properly and the rules that apply to } \\
\text { the benefits of Kampung Muka } \\
\text { residents. }\end{array}$} & $\begin{array}{l}\text { The role of Ibu Imeh as Chairman of PKH shows the } \\
\text { belief of the residents to Ibu Imeh and the organization } \\
\text { to help maintain the survival of Kampung Muka } \\
\text { residents related to the welfare of children's education. }\end{array}$ \\
\hline & $\begin{array}{l}\text { Ibu Rere dan Family in Kampung Muka's } \\
\text { Development }\end{array}$ \\
\hline $\begin{array}{l}\text { Forming } \\
\text { In } 2006 \text { is the year that was a } \\
\text { burgeoning of immigrant residents } \\
\text { from outside Jakarta to seek a new } \\
\text { livelihood in Kampung Muka. }\end{array}$ & $\begin{array}{l}\text { Coming from Pemalang in } 2006 \text {, Ibu Rere and her } \\
\text { husband began to get acquainted with other residents } \\
\text { with the help of his brother. The process of adaptation } \\
\text { continued until finally Bu Rere also found an } \\
\text { opportunity to open warung in her house like other } \\
\text { residents. }\end{array}$ \\
\hline $\begin{array}{l}\text { Performing } \\
\text { Kampung Muka has made the rules } \\
\text { applicable concerning livelihoods in } \\
\text { Kampung Muka. Therefore, many } \\
\text { migrant residents who directly } \\
\text { follow the rules that already exist. }\end{array}$ & $\begin{array}{l}\text { Ibu Rere and her husband easily follow the rules that } \\
\text { apply. She did not experience conflict when trying a } \\
\text { new life in Kampung Muka, and other residents helped } \\
\text { each other to socialize in the kampung. }\end{array}$ \\
\hline
\end{tabular}

Table 2 The Implementation of Cohousing's Component in Kampung Muka

\begin{tabular}{c|c}
\hline \multicolumn{1}{c}{$\begin{array}{c}\text { The six components of } \\
\text { Co-housing }\end{array}$} & \multicolumn{1}{c}{$\begin{array}{c}\text { The six components implemented } \\
\text { in Kampung Muka }\end{array}$} \\
\hline Participatory process & $\begin{array}{l}\text { Each member of the community indirectly } \\
\text { participate in the process of kampung's } \\
\text { development; }\end{array}$ \\
\hline
\end{tabular}

\footnotetext{
${ }^{7}$ Perusahaan Jawatan Kereta Api -now it is called PT. Kereta Api Indonesia- a state-owned enterprises that provide train transportation services.
} 


\begin{tabular}{|c|c|}
\hline & $\begin{array}{l}\text { - The residents still active with cooperation to } \\
\text { help others in making the livelihood of each } \\
\text { member of the community; } \\
\text { - Initiatives to build common areas such as } \\
\text { mosques that prove the level of participatory } \\
\text { process in kampung is high. }\end{array}$ \\
\hline Deliberate neighborhood design & $\begin{array}{l}\text { - Each member of the community active in } \\
\text { creating an acceptable physical environment } \\
\text { for their neighborhood; } \\
\text { - It is proven by the majority of Kampung Muka } \\
\text { residents make the alley in front of their house } \\
\text { as a communal space for chatting with other } \\
\text { residents; } \\
\text { - This phase is shown how accidentally the } \\
\text { participatory process has succeeded happen in } \\
\text { Kampung Muka's development. }\end{array}$ \\
\hline Extensive common facilities & 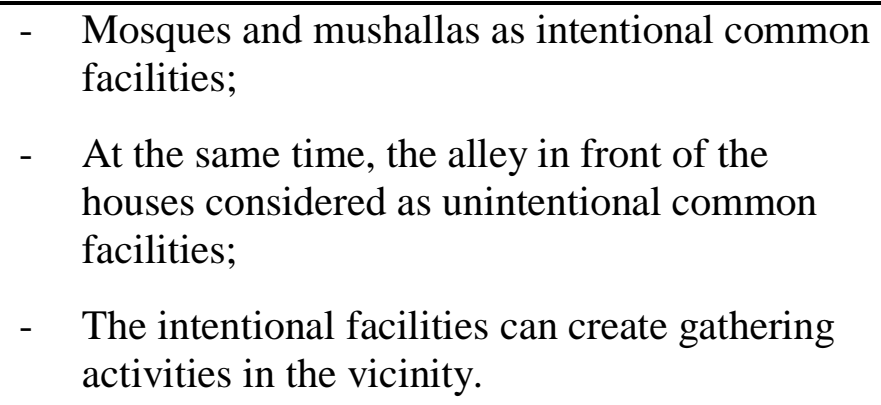 \\
\hline Complete resident management & $\begin{array}{l}\text { A system that is not deliberately enforced in } \\
\text { Kampung Muka to organize the community; } \\
\text { - For certain time and conditions, Kampung } \\
\text { Muka residents have certain meetings to hold } \\
\text { deliberations for the sustainability of kampung. }\end{array}$ \\
\hline Non-hierarchal structure & 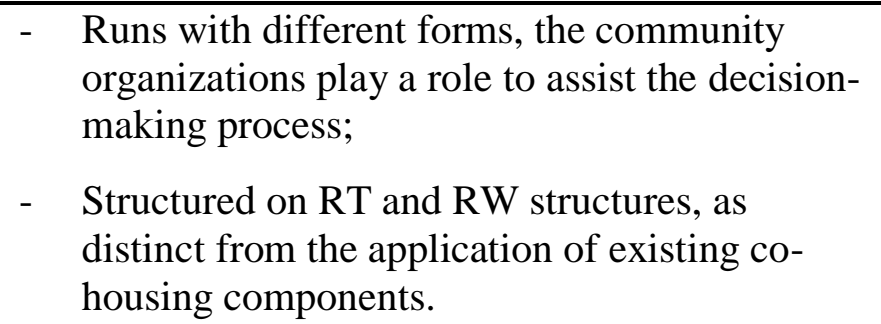 \\
\hline Separate income sources & $\begin{array}{l}\text { - The residents have their income and are } \\
\text { entitled to manage their income as desired; } \\
\text { - However, Kampung Muka has a budget system } \\
\text { or shared dues for the maintenance of existing } \\
\text { facilities in Kampung Muka. }\end{array}$ \\
\hline
\end{tabular}




\subsection{The Participatory of Community in Kampung Muka}

With the four stages of community formation within Kampung Muka and its components, it shows that the structure of Kampung Muka's establishment is based on "deliberate" or intended to be formed with a specific purpose. Planning of joint facilities and management of space and facilities in Kampung Muka then support the movement of citizen involvement in the kampung. The involvement in every process of kampung formation shows the principle of community that runs in Kampung Muka fosters the value of participators of the people in the kampong and fosters a sense of community willingness.

The existence of musalla and warung then create a negotiation of space in the alley. For example, Mrs. Rere as one of the residents who open a food stall expands the area of sale to the alley of the front of the shop which is also home. The existence of buyers who sit to eat in the alley area does not make other residents disturbed and vice versa. Also, there is also Pak Ujang, meatballs seller around, which makes the front area of the school as a selling area when the school is closed. The school's pick-up seats serve as a seat for the buyers to create a new space in the alley.

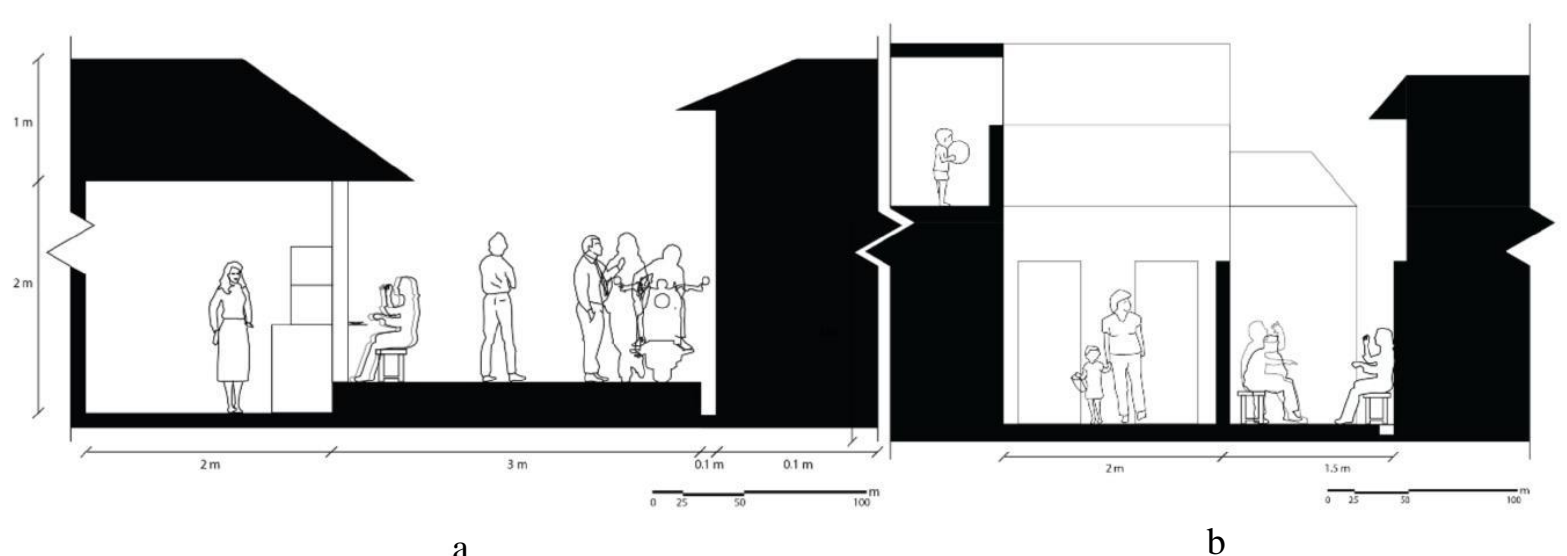

Figure 3 Illustration of the using of the alley; (a) The area in front of Ibu Rere's store; (b) The area of Pak Ujang's selling space

Source: Field report, 2018

\section{CONCLUSION}

Tuckman's (1965) theory relates to the phases of the formation of a community in co-housing that took place in Kampung Muka but more dynamic than the theories already proposed. The establishment of social and public facilities is done after the process of recognizing and mutual belonging to each other is formed to foster participatory process in Kampung Muka residents who are done to develop the kampung. Based on the analysis conducted, the participation of residents in Kampung Muka is very high, seen from how the people mutually maintain each other's territory and agree in determining the common spaces in Kampung Muka.

Negotiating spaces that occurred in Kampung Muka is seen from the division of the use of the front of the alley home to meet the needs of groups and individuals which further impact on the spread of gathering points formed by its citizens. This showed that the social space formed in Kampung Muka is not accidental. The form of interaction space in Kampung Muka then becomes the thing that distinguishes between the application of the existing co-housing concept with the application that runs in Kampung Muka by the local context of a kampung kota. The participatory process in Kampung Muka's residents is a form of embodiment of the existing cohousing concept. However, some applicable concept components are applied in a different form 
from the existing co-housing concept. It can be seen with the RT, RW, and groups of PKH mothers as community organizations.

\section{REFERENCES}

Durrett, C., 2009. A Community Approach to Independent Living: The Senior Cohousing Handbook. Canada: New Society Publishers.

Jarvis, H., 2010. Saving Space, Sharing Time : Integrated Infrastructures of Daily Life in Cohousing.

Kim, G., 2017. How Cohousing Can Make Us Happier (and Live Longer) - Grace Kim. Retrieved from Youtube: https://youtu.be/mguvTfAw4wk

Levinson, D., Christensen, K., 2003. Encyclopedia of community: From the village to the virtual world (Vol. 1). Sage.

McCamant, K., 1999. A Model for Reinvigorating Urban Neighborhoods. Retrieved from New Village Building Sustainable Cultures: http://www.newvillage.net/Journal/Issue1/1urbaninfill.html

McCamant, K., Durrett, C., 1998. Cohousing : A contemporary approach to housing ourselves. Berkeley: Ten Speed Press.

Ruiu, M.L., 2015. The Effects of Cohousing on The Social Housing System : The Case of The Threshold Centre. Springer, 632.

Ruiu, M.L., 2017. Participatory Processes in Designing Cohousing Communities : The Case of The Community Project. Housing and Society.

Tuckman, B.W., 1965. Developmental Sequence in Small Groups. Psychological Bulletin, 384399.

Williams, J., 2005. Designing Neighbourhoods for Social Interaction : The Case of Cohousing. Journal of Urban Design. 